\title{
Handicapped Design Projects in a New Engineering Honors Course
}

\author{
Wayne Walter, Mark Smith \\ Kate Gleason College of Engineering \\ Rochester Institute of Technology \\ Rochester, NY 14623
}

\begin{abstract}
As part of a new Honors Program within the Kate Gleason College of Engineering at the Rochester Institute of Technology (RIT), a multidisciplinary design project has been recently introduced as a two-course sequence ( 1 credit each quarter), taken by honors students during the winter and spring of their Freshman year. Instead of utilizing the design project as a capstone experience, the Honors Design Course at RIT is focused on freshman, to foster passion for product development as early as possible in the undergraduate learning experience. During this inaugural year, students have targeted the handicapped population, consistent with servicelearning objectives for the Honors Program as well as the students' collective desire to use their engineering skills to improve quality of life. This paper will provide the framework and details surrounding the Honors Design Course in the context of the overall Honors Program at RIT.
\end{abstract}

\section{Introduction}

Product design courses have become an integral part of the undergraduate engineering experience. Last year's ASEE Conference, for example, contained numerous papers on new programs and important findings from existing programs [1-9]. Traditionally, these design courses have taken the form of a capstone project or formal course for students in the final year or two of a baccalaureate program, but many schools have instituted courses and fully integrated product development programs beginning with first year students $[6,7,10]$. ABET has also recognized the importance of a team-based design experience for necessary skill development in undergraduate engineering students [11].

Many authors have suggested and documented a number of benefits associated with collaborative design projects $[2,3,5-8,10,14-16]$ : innovative problem solving, improved handling of complexity and ambiguity, enhanced communication skills and self-confidence, improvements in team building and interpersonal interactions, etc. Beyond traditional benefits associated with almost any type of realistic design problem, Green, et. al. [1], have described incremental benefits to "service-oriented" projects, such as intense student enthusiasm, realizable scope, and broadening horizons into philanthropic concerns. From an accreditation perspective, ABET recognizes the importance of service learning as a contributor to the societal responsibilities of engineers [12].

At RIT, first and second year Honors students elected to tackle the challenge of designing assistive devices for handicapped individuals at a local children's center and visiting nurse agency. Other authors have described similar projects $[9,18]$ and incremental benefits to students, such as empathy for people with disabilities and significant personal satisfaction. Over 
the past several years, upper level students at RIT in the Machine Design and Senior Design courses have been involved in the design and fabrication of a number of assistive devices for individuals with special needs. Students who have worked on these projects gained a great deal of satisfaction from seeing their prototypes utilized by others less fortunate. We anticipate a similar level of satisfaction for our Honors students.

\section{The Hon ors Program}

The RIT Honors Program, which extends throughout the entire period of the student's undergraduate program at RIT, aspires to provide a comprehensive education of the highest quality consisting of three components: professional opportunities within the student's college, four enhanced general-education courses, and specially designed experiential-education activities designed to meet the educational, career and personal objectives of RIT's most talented students [19].

In their freshman and sophomore years, Honors students are required to participate in a minimum of two complementary learning activities per year. Among these activities are special research projects, community service projects, leadership activities and travel.

The following qualifies for honors credit [19]:

- Participation in a program or event that helps develop a student's skills for life and career success also may qualify for honors credit.

- Participation in a community service program or an event in which a student gives back to the RIT or Rochester community may qualify for honors credit.

- Participation in professional/cultural trips organized by the student's home college.

- An activity or event students propose themselves. This may be an individual activity, but it may also be something a student organizes with other RIT students.

\subsection{Admission to the Program}

Each year, the RIT Honors Program admits approximately 100 new students from the university's 2,300 entering freshmen. These outstanding students represent the top 5\% of RIT's accepted applicants in each participating college, or just over 1\% of all students applying for freshman admission to RIT. In selecting students for the RIT Honors Program the Admissions Committee looks for a combination of characteristics that will support the student in meeting the demands associated with being a member of the Honors Program. For entering students, this potential is demonstrated largely by high-school grades, test scores, class standing, recommendations and a record of extracurricular activities and personal interests.

Students currently at RIT are able to apply to enter the honors program for second-year and thirdyear entry. Students who meet the following criteria are eligible to apply [1]. For Sophomore Entry (decision made after the winter quarter of the first year):

- $\quad 3.6$ or higher GPA

- Minimum of 28 RIT credits

- Nomination and strong recommendation by a faculty member

- Evidence of extracurricular activity at RIT

For 3rd Year Entry (decision made after the winter quarter of the 2ndyear): 
- 3.6 or higher GPA

- Minimum of 70 RIT credits completed (45 credits for external transfer students) with at least 90 credits remaining as an Honors student

- Nomination and strong recommendation by a faculty member

- Evidence of extracurricular activity at RIT

\section{The Honors Design Two-Course Sequence}

In the first course they design a product or system, and in the second course they build and test a working prototype. With each course being only one credit, projects need to be carefully selected to be doable in the limited time available.

\subsection{Honors Design Course Objectives}

The following are the high-level course objectives:

- Support the overall goals of the Honors Program at the Institute: to provide speciallydesigned experiential activities to meet the educational, career, and personal objectives of RIT's most talented students.

- Support the primary theme of the honors program in the College of Engineering: multidisciplinary design in a global environment.

- Better prepare students for careers as product development engineers: interaction with customers, discovery (identification of needs and opportunities), multidisciplinary teams and organizational dynamics, systems thinking, application of tools and principles to real design problems, and appreciation for the product development process.

- Do feasibility testing, as a precursor to broader implementation within the college. Honors students represent an ideal test population: limited sized group, highly competent and constructive, engaged.

Detailed course objectives can be summarized as:

- Emphasize discovery and creative problem solving. Gain appreciation for the process of gathering customer needs and wants, and instill the importance of engineers' participation in this process. Enhance skills in listening, observing, questioning, and documentation, and provide the realization that customers cannot always express their needs and wants.

- Understand the differences between requirements and specifications, between gathering needs and proposing solutions. The tendency to jump to potential solutions or begin the design process before thoroughly understanding the problems or opportunities is a common attribute of engineers that we'd like to extinguish early in their educational experience.

- Develop skills in utilizing powerful tools for the product developer: Quality Function Deployment (QFD), Pugh Concept Selection, etc.

- Improve communication skills: interpersonal, written and oral. Of particular importance is the development of team skills - respect for diversity of opinion, conflict resolution, team decisionmaking, and balance.

- Enhance decision-making and risk management skills. A related skill is the ability to initiate and solve highly unstructured problems. Unlike many well-defined problems that students are exposed to in conventional classes, nothing is clear-cut in an open-ended design project. Uncertainty and ambiguity characterize such a project, and it is invaluable for engineering students to deal with these "real-world" issues. 
- Enhance systems thinking, the comprehensive examination of the "global" challenges and characteristics.

\subsection{Anticipated Benefits:}

In addition to the benefits outlined above, several unique characteristics of RIT's Honors Design Course are anticipated to provide additional rewards:

- By engaging students so early in their college experience, we hope to see their interest and enthusiasm grow during their undergraduate years.

- By focusing on the handicapped population, we hope to build a stronger sense of the young engineer's ability to impact peoples' lives, as opposed to simply creating nifty widgets. Sharpening a sense of social responsibility in young engineers may be another desirable byproduct of this particular design experience.

- Emphasis on the discovery process and customer intimacy is intended to underscore the integral role played by engineers in all phases of the product development process, and the opportunities that may present themselves through active participation in the early phases of the process.

\section{Design Process for Projects}

As freshman with very limited analysis and design abilities, KGCOE students will be presented with information for their project on a need-to-know- basis associated with the product development process including requirements identification, concept development, detailed design, prototype development, and test and refinement. The focus of the requirements identification phase is on gathering customer and user requirements, and developing a mission statement. Student deliverables here are a requirements document and a mission statement. In the concept development phase, identification of alternative concepts and selection of the best concept using the Pugh Concept Selection Matrix is described. Some basic system engineering tools are presented including the first house of Quality Function Deployment (QFD), and FAST and Functional Flow Block Diagrams. In the detailed design and prototype development portion, product specifications, project milestones, design sketches and mockups for feasibility are covered. This is followed by a discussion of validation testing in the laboratory and at the customer site.

\section{Project Activities}

At an initial rollout meeting, a marketing specialist explained the need for student teams to develop a mission statement and a passion for what they are doing for their customer. It is a lack of this passion, he explained, that typically causes companies to lose market share. He also discussed a process for teams to develop a requirements document that should be agreed to by their customer. At the second meeting, four teams visited the Mary Cariola Center for Handicapped Children (MCC). Many of their clients are children that are physically or developmentally disabled due to Cerebral Palsy, Spinal Bifida, and others. All are wheel chair bound. The other four teams heard a presentation by staff from the Finger Lakes Visiting Nurse Service (FLVNS). Their clients are elderly with limited strength and mobility. The intent of the second meeting was to help teams identify projects to develop assistive devices. At the third meeting, teams were flip-flopped so that all teams got a chance to experience the issues at both agencies. At this point in time, a number of potential projects have been identified as a result of 
visiting MCC. These include:

- A rocker base for a conventional wheelchair (wheelchair will roll onto it and be secured in place).

- Supine kneeler (a device to support a child while kneeling that would otherwise be unable to support their own weight).

- "Jet base" mobile platform to allow a child to roll around on the floor lying down, propelled by their hands, with an adjustable speed control.

- Tactile sensing cell for squeezing and hugging.

- Pool floats and pool bench for pool therapy time.

- Pager-like call device to allow staff to report emergencies within their room.

- Small position-adjustable table.

- Devices to assist children in paper making projects including a device to hold water and pour it, and a device to dip a screen in a paper-pulp mixture and remove it.

- Device to support a child's arm while the child is sitting in a wheelchair using an educational toy.

- Protective apparel for a child who often injurers his knees and legs while playing.

Representatives from both agencies will come back to campus at meeting four, to answer questions and to help teams brainstorm specific projects. Students interested in FLVNS projects will get an opportunity to visit selected elderly clients in their homes to better identify their needs for assitive devices. After selecting and focusing on a specific project, teams will then develop their mission statement and requirements document during week five, deliverables due week six. For the balance of the quarter, during weeks seven through ten, teams will develop a concept for their project and a proposal, including a detailed bill of materials and budget, to build a prototype during the following spring quarter.

During the spring, student teams will revise and refine their design, fabricate their prototypes, and test them on campus before bringing them to Mary Cariola Center for initial trials with kids, or to FLVNS for use by their clients. The KGCOE has an excellent machine shop facility where teams will have the opportunity to fabricate their prototypes, and many of our students are currently taking a Materials Processing course, which will help greatly in getting parts made. Initial testing to quantify the prototype's performance will be done on campus in KGCOE laboratories. A budget to cover the fabrication costs outlined by each team in their winter quarter final report, is being provided by RIT, and may need to be revised with their designs. Although safety is a prime design requirement for all projects, yet to worked out are issues of liability, should injuries occur, however minor. Regarding intellectual property rights, it is RIT policy that RIT students, and faculty, if appropriate, retain their IP rights unless they explicitly assign them to a sponsor. It is entirely possible that one these projects may lead to a patentable device that could interest a sponsoring company in a market study, or future funding possibilities from the National Institutes of Health (NIH) etc. If this is the case, students will be free to pursue these opportunities. This might very well lead to a Senior Design project for these students later in their RIT career.

\subsection{Challenges}

Many authors have documented challenges associated with engineering design courses and 
projects $[13,14]$. Because of the few hours allocated to the Honors Design course, the shortage of time represents the single biggest issue. Students are not expected to devote significant time outside of class ( 2 hours/week for 20 weeks), since they are already carrying full course loads. This presents a number of interesting challenges:

- Matching expectations to available time. It is critical that the students have a positive experience, which implies adequate time to complete the project as well as a meaningful outcome. Given the shortage of time, the emphasis of the project is on discovery versus delivery. Students must demonstrate proof-of-concept but are not required to produce a working prototype.

- Balancing time devoted to tutorials and special topics with time available to work on the projects themselves. Providing tutorials and seminars on key product development processes and tools is essential to maximizing value and minimizing frustration for the students. We have adopted a strategy of using event-driven training to insure that students are prepared each week to address critical phases of the design project. Given two hours per week, it is very difficult to provide adequate preparation without seriously compromising students' ability to work on their projects.

Although usually a major concern, grading of the Honors Design project has been de-emphasized by design. The primary intent of this low credit hour course is to foster a strong sense of ownership and excitement. The Dean set reasonably low performance expectations for an "A," and the faculty mentors assigned to each team will not participate in the grading of their respective teams. Peer review is being utilized primarily as feedback to team members, although it is also meant to foster consistent effort within each team.

\section{Conclusions}

A multidisciplinary design project has recently been introduced to freshman and sophomore honors students at RIT. During this inaugural year, students have targeted the handicapped population, consistent with service-learning objectives for the Honors Program as well as the students' collective desire to use their engineering skills to improve quality of life. We hope that these projects will be as well received by our students as previous handicapped design projects in Machine Design and Senior Design have been. Here, students received much satisfaction from seeing their prototypes used by handicapped children.

\section{Bibliography}

1. Green, M., et.al., "Integrating Service-Oriented Design Projects in the Engineering Curriculum," Proceedings of the 2002 ASEE Annual Conference \& Exposition, session \#3660.

2. Mills, J., "A Case Study of Project-Based Learning in Structural Engineering," Proceedings of the 2002 ASEE Annual Conference \& Exposition, session \#2793.

3. Knecht, R.D., et. al., "Integrating Process and Product: Improving Engineering Education Through the Team Experience," Proceedings of the 2002 ASEE Annual Conference \& Exposition, session \#2793.

4. Vavreck, A.N., "Project Management Applied to Student Design Projects," Proceedings of the 2002 ASEE Annual Conference \& Exposition, session \#2642.

5. Carlson, L.E. and Sullivan, L.E., "Exploring Entrepreneurship Through Product Development," Proceedings of the 2002 ASEE Annual Conference \& Exposition, session \#1354. 
6. Okudan, G.E. and Devon, R., "Embedding Engineering Management into Product Design Education," Proceedings of the 2002 ASEE Annual Conference \& Exposition, session \#1327.

7. Ochs, J.B., et. al., "Cultivating an Entrepreneurial Spirit Through Cross-Disciplinary Student Teams in Freshmen Projects Course," Proceedings of the 2002 ASEE Annual Conference \& Exposition, session \#3454.

8. Hollar, K., et. al., "Bugbots! A Multidisciplinary Design Project for Engineering Students," Proceedings of the 2002 ASEE Annual Conference \& Exposition, session \#2426.

9. Brackin, P. and Gibson, J.D., "Capstone Design Projects: Enabling the Disabled," Proceedings of the 2002 ASEE Annual Conference \& Exposition, session \#2625.

10. Carlson, L.E., et. al., "First Year Engineering Projects: An Interdisciplinary, Hands-on Introduction to Engineering, Proceedings of the 2000 ASEE Annual Conference \& Exposition, pp. 2039-2043.

11. "Criteria for Accrediting Engineering Programs," Engineering Accreditation Commission, ABET, 2002, http://www.abet.org.

12. ABET, "Criteria for Accrediting Engineering Programs Effective for Evaluations During the 2001-2002 Accreditation Cycle," http://www.abet.org.

13. Moor, S. S., and Drake, B., "Addressing Common Problems in Engineering Design Projects: A Project Management Approach," Journal or Engineering Education, July 2001, pp. 389-395.

14. Dutson, A.J., "A Review of Literature on Teaching Engineering Design Through Project-Oriented Capstone Courses," Journal of Engineering Education, v. 86, no. 1, 1997, pp. 17-28.

15. Pimmel, R., "Cooperative Learning Instructional Activities in a Capstone Design Course," Journal of Engineering Education, July 2001, pp. 413-421.

16. Shirland, L. E., "Collaborative Teaching of Integrated Product Development: A Case Study," IEEE Transactions on Education, v. 43, no. 3, August 2000, pp. 343-348.

17. Davis, D.C., et. al., "Engineering Design Assessment Processes and Scoring Scales for Program Improvement and Accountability," Journal of Engineering Education, April 2002, pp. 211-221.

18. Kroll, D.E. and Strubhar, A.J., "Interdisciplinary Teams? An Industrial Engineering/Physical Therapy Project," Proceedings of the 2000 ASEE Annual Conference \& Exposition, session \#2557.

19. URL: http://www.rit.edu/\%7E620www/honors.

\section{WAYNE W. WALTER}

Wayne Walter is the James E. Gleason Professor of Mechanical Engineering at RIT. He received his Ph.D. in Mechanics from Rensselaer Polytechnic Institute. Wayne has worked for the U.S. Army, Rochester Products and Delco Products Divisions of General Motors, and Xerox, and is a registered professional engineer (P.E.) in New York State. He can be reached at wwweme@rit.edu.

MARK SMITH is Director of the Product Development (MPD) and Manufacturing Management and Leadership (MML) programs at the Rochester Institute of Technology. Prior to joining RIT, he spent nearly 20 years in medical electronics R\&D, most recently with Kodak where he was Product Development Manager for the Cardiology electronics business. Mr. Smith has an MS in Electrical Engineering from the University of Rochester. He can be reached at mwspd21@rit.edu. 